\title{
O DIREITO HUMANO A VIVER EM UM MEIO AMBIENTE SAUDÁVEL E EQUILIBRADO À LUZ DOS SEUS VÍNCULOS COM OUTROS DIREITOS HUMANOS NA IMINÊNCIA DO PACTO GLOBAL AMBIENTAL
}

\author{
THE HUMAN RIGHT TO LIVE IN A HEALTHY AND \\ ECOLOGICALLY SOUND ENVIRONMENT IN THE LIGHT OF ITS \\ LINKS WITH OTHER HUMAN RIGHTS IN THE IMMINENCE OF \\ THE GLOBAL ENVIRONMENTAL PACT
}

\author{
Lívia Gaigher Bósio Campello ${ }^{1}$
}

Rafaela de Deus Lima²

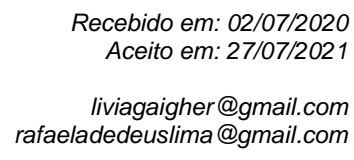
rafaeladedeuslima@gmail.com

\begin{abstract}
Resumo: O presente artigo analisa a tutela do direito humano ao meio ambiente saudável e equilibrado diante da crise ambiental global no Antropoceno. Nesse intuito, busca, inicialmente, estudar a referida crise e suas manifestações como marco do Antropoceno. Em seguida, analisa o processo de afirmação do direito humano ao meio ambiente no âmbito internacional. Por fim, aborda o iminente Pacto Global para o Meio Ambiente em prol da tutela do meio ambiente como direito humano. Para tanto, utiliza a pesquisa exploratória e descritiva, bibliográfica e documental, com análise de obras, artigos científicos e documentos internacionais. O método é dedutivo, partindo de conceitos gerais em busca de sua particularização.
\end{abstract}

Palavras-chave: Antropoceno. Crise ambiental global. Direito Humano ao Meio Ambiente. Meio ambiente. Pacto Global para o Meio Ambiente.

\begin{abstract}
This present paper intends to analyze the protection of the Human Right to a healthy and ecologically sound environment in the Anthropocene's ecological crisis context. For this purpose, we start from the ecological crisis as an Anthropocene's landmark. Furthermore, we analyze the affirmation of the Human Right to a healthy and ecologically sound environment on the international context. In the end, we approach the imminence of the Global Environmental Pact for environment's protection as a Human Right. For this, we use the exploratory and descriptive, bibliographic and documental research, with an analysis of books and scientific articles. The method is deductive, starting from a universal concept until its particularization.
\end{abstract}

Keywords: Anthropocene. Global environmental crisis. Human Right to an Environment. Environment. Global Pact for the Environment.

\section{INTRODUÇÃO}

A crise ambiental global é um dos principais desafios do século XXI e a complexidade dessa questão decorre especialmente da sua característica transfronteiriça e da ligação entre suas inúmeras manifestações. Esse quadro alarmante, segundo apontado por cientistas de todo o planeta desde a década de 1960, emana da interferência humana na natureza sem precedentes, por meio da qual houve apropriação exagerada da natureza pelo homem, pelo fato de que muitas vezes é vislumbrada como mero recurso dotado de valor econômico.

\footnotetext{
${ }^{1}$ Universidade Federal do Mato Grosso do Sul. Mato Grosso do Sul. Brasil.

2 Universidade Federal do Mato Grosso do Sul. Mato Grosso do Sul. Brasil.
} 
O direito humano a viver em um meio ambiente saudável e equilibrado à luz dos seus vínculos com outros direitos humanos na

Consequentemente, essa ideia de natureza objeto e os resultados de sua exploração de modo indiscriminado colaboraram para que o ser humano fosse colocado como uma força geológica capaz de modificar a Terra ao ponto de marcar o surgimento de uma nova época denominada Antropoceno, que tem como marco as atividades humanas e suas "pegadas" no planeta.

Nesse cenário de crise ambiental global, novas demandas emergem no que se refere aos direitos humanos, uma vez que as consequências decorrentes dessa crise se apresentam constantemente como violadoras desses direitos e, especialmente, do direito ao meio ambiente saudável e equilibrado. Logo, faz-se necessário analisar os direitos humanos também pelas lentes do meio ambiente, com o intuito de construir uma maior proteção para ambos. Desse modo, o presente artigo tem como objetivo geral verificar como se dá a tutela do direito humano ao meio ambiente saudável e equilibrado. Para tanto, o trabalho será dividido em três partes. A primeira buscará expor a crise ambiental global e suas consequências na nova época geológica do Antropoceno. A segunda analisará a afirmação do direito humano ao meio ambiente por meio dos instrumentos internacionais que compõem o sistema de governança ambiental e de direitos humanos. Por fim, a terceira examinará o iminente Pacto Global para o Meio Ambiente e seus efeitos no âmbito do sistema de proteção aos direitos humanos.

A fim de alcançar os objetivos mencionados, será utilizada a pesquisa exploratória e descritiva no que tange aos fins e bibliográfica e documental quanto aos meios, com uma análise realizada por meio de obras, artigos científicos e documentos internacionais. O método adotado será o dedutivo, partindo de conceitos gerais e buscando sua particularização.

\section{A CRISE AMBIENTAL GLOBAL NA NOVA ÉPOCA GEOLÓGICA DO ANTROPOCENO}

O ser humano sempre manteve uma relação com o meio que o rodeia. Na história não faltam elementos evidenciando que, há muito tempo, os seres humanos têm consciência de sua inserção na natureza ${ }^{3}$. Contudo, tal ligação, e o modo como é vislumbrada pelo homem, modificou-se no decorrer do tempo. Em um primeiro momento, a natureza "[...] [era considerada como] a matriz do homem e sua mãe nutridora. Assim, a Terra [era] sagrada e os animais, como as plantas, [eram] dignos de respeito [...]" (KISS; BEURIER, 2004, pp. 12-13); desse modo, a natureza apresentava fins que ultrapassavam o homem, sendo este apenas uma parte integrante desta (OST, 1997).

A relação do homem com a natureza foi modificada com o advento do mercantilismo, da expansão agrícola e industrial, bem como os avanços da ciência moderna do século XVI e XVII, que trouxeram instrumentos de intervenção sem precedentes (em razão do novo arsenal tecnológico desenvolvido) no meio natural (SARLET; FENSTERSEIFER, 2014).

\footnotetext{
3 "No budismo, um texto datando do século III, antes de nossa era, relata um discurso realizado a um rei para lhe relembrar que os pássaros do céu e os bestiais têm o mesmo direito à vida e à liberdade de movimento que o próprio rei: a terra pertence ao povo e a todos os seres vivos, o rei é somente o guardião. [Ainda], inúmeras outras civilizações mantinham, em sua origem, um vínculo místico com a natureza; [a cosmologia começa] por um 'casamento' entre a Terra e o Céu ou o Tempo. Em culturas africanas, ameríndias ou asiáticas, a Terra é a Deusa mãe da humanidade" (KISS; BEURIER, 2004, p. 11-12).
} 
A revolução científica foi acompanhada pela mecanização e matemática da natureza, que contradiziam as crenças medievais baseadas nas qualidades intrínsecas e nos aspectos animistas (espirituais) da natureza. Na época, coisas naturais, incluindo animais, passaram a ser vistas como meras máquinas, cuja anatomia e função poderiam ser reveladas pela física e química e, eventualmente, pela matemática.

O capitalismo 4 colaborou para instrumentalização da natureza, transformou a natureza em produto, que passou a ser vislumbrada como objeto dotado de valor econômico a ser explorado livremente pelo ser humano. Assim "o homem [foi] alçado a detentor da natureza, uma vez que tem o poder de transformá-la e dominá-la” (OST apud CAMPELLO; LIMA, 2018).

A ideia de natureza objeto e sua apropriação pelo ser humano colaboraram para a adoção de um modelo de desenvolvimento pautado no rápido crescimento e na utilização indiscriminada dos recursos naturais. Esse cenário desencadeou a atual crise ambiental global enfrentada pela humanidade, não restando dúvida de que as ações humanas encontram-se como causas dos maiores desafios ambientais, conforme havia anunciado Rachel Carson em seu livro Primavera Silenciosa (Silent Spring) ao afirmar que "nenhuma bruxaria ou ação inimiga silenciou o renascimento da vida nova nesse mundo acometido, as pessoas fizeram isso elas próprias" (CARSON, 2010).

A crise ambiental, diferentemente de outras crises já enfrentadas pela humanidade, torna-se extremamente complexa devido ao seu caráter transfronteiriço ${ }^{5}$ e pelo fato de que suas inúmeras manifestações encontram-se interligadas, com destaque para as mudanças climáticas, a poluição atmosférica, a perda de diversidade biológica e a crise hídrica.

As mudanças climáticas já foram destacadas como um dos maiores desafios do século XXI, tendo em vista suas consequências econômicas, sociais e ambientais. As suas principais causas estão atreladas ao aumento da concentração de $\mathrm{CO}_{2}$ na atmosfera ${ }^{6}$, que já cresceu em aproximadamente $31 \%$ desde a Revolução Industrial, totalizando um lançamento aproximado de 23 bilhões de toneladas de $\mathrm{CO} 2$ na atmosfera por ano. Outro fator que agrava esse quadro é o desmatamento ${ }^{7}$, pontuado - pela $\mathrm{FAO}^{8}$ - como a segunda maior causa das mudanças climáticas, sendo responsável pela emissão de $20 \%$ dos gases que agravam o efeito estufa (FAO, 2018).

Dentre as consequências decorrentes desse problema destacam-se a elevação da temperatura - o que já foi verificado, entre outros, com o verão europeu de 2019 em que a França

\footnotetext{
${ }^{4}$ Críticos do capitalismo descreveram a "racionalidade econômica" como a principal causa de destruição ambiental, porque transforma ativos naturais em produtos com o objetivo de acomodar o estilo de vida dos consumidores.

5 "Os cursos d'água, os oceanos, a atmosfera, a fauna e flora não conhecem fronteiras: um impacto maior no interior das fronteiras de um país podem provocar repercussões no meio ambiente exteriores às fronteiras, seja no território de outro país, seja em alto mar" (KISS; BEURIER, 2004, p. 12-13).

${ }^{6}$ Conforme os dados apresentados pela WWF, o $\mathrm{CO} 2$ é responsável por mais de $80 \%$ da poluição que gera o aquecimento global. Ainda, $97 \%$ do $\mathrm{CO} 2$ emitido pelos países industrializados são oriundos da queima de carvão, óleo e gás que são utilizados na produção de energia.

${ }^{7}$ As florestas apresentam um papel fundamental ao auxiliar no combate às mudanças climáticas, funcionando como filtro e absorvendo cerca de 2 bilhões de toneladas de CO2; contudo, quando são desmatadas, as coberturas vegetais do planeta se transformam em motores do aquecimento global.

${ }^{8}$ Food and Agriculture Organization of the United Nations.
} 
O direito humano a viver em um meio ambiente saudável e equilibrado à luz dos seus vínculos com outros direitos humanos na iminência do pacto global ambiental

alcançou temperaturas recordes de até $46^{\circ} \mathrm{C}$-, o derretimento e desaparecimento das geleiras, a elevação do nível dos oceanos e sua acidificação, o desaparecimento de ilhas - surgindo os deslocados ou refugiados ambientais ${ }^{9}$-, bem como o aumento de secas e inundações devido a intensidade das chuvas.

Essa problemática encontra-se intimamente relacionada com a poluição atmosférica, gerando consequências desastrosas para a saúde humana. Segundo o relatório lançado pela Organização Mundial da Saúde (OMS), no final de 2018, nove em cada dez pessoas respiravam um ar poluído, o que resulta em uma mortalidade de 7 milhões de pessoas anualmente. Ainda, estima-se que em 2016 cerca de 600.000 crianças morreram de infecções respiratórias agudas devido ao ar poluído (WHO, 2018).

Ademais, a crise ambiental afeta profundamente a diversidade biológica e, como consequência, há uma redução do número de espécies e o aumento das taxas de extinção. Estimase que apenas entre os anos de 1970 e 2014 houve uma redução média de $60 \%$ da população de vertebrados, enquanto - atualmente $-45 \%$ dos invertebrados terrestres, $34 \%$ dos invertebrados de água doce e $25 \%$ dos invertebrados marinhos encontram-se em risco de extinção (UN, 2019).

Por fim, a questão hídrica, que é agravada pelo aumento do uso e pela contaminação dos recursos hídricos, também traz inúmeros desafios. Com efeito, os dados científicos demonstram que o uso da água cresce a uma taxa de $1 \%$ ao ano desde a década de 1980 devido ao crescimento populacional, ao desenvolvimento socioeconômico e às mudanças dos padrões de consumo (ONU, 2019). Além do aumento da demanda pela água, outro ponto crucial da crise hídrica se dá pelo fato de que mais de dois bilhões de pessoas vivem em países que enfrentam estresse hídrico (ONU, 2019), enquanto cerca de 4 bilhões experimentam escassez severa de água durante pelo menos um mês ao ano (ONU, 2019).

Esse cenário de crise ambiental global e de mudança na relação homem-natureza despontou na nova época geológica ${ }^{10}$ denominada Antropoceno, em que "nós, a espécie humana, teríamos, no passado, [...], destruído a natureza até alterar o Sistema Terra” (BONNUEIL; FRESSOZ, 2013, p. 12).

\footnotetext{
${ }^{9}$ Em 21 de janeiro de 2020 o Comitê de Direitos Humanos da ONU proferiu sua primeira decisão no que concerne à busca de proteção contra os efeitos das mudanças climáticas. O requerente - loane Teitiota - é um habitante do país insular Kiribati, no Pacífico, e apresentou - em 2015 - uma queixa perante o Comitê, depois de ser deportado da Nova Zelândia, alegando que o seu direito à vida havia sido violado, pois o aumento do nível do mar e os outros efeitos das mudanças climáticas tornaram sua terra inabitável, forçando-o a migrar para a Nova Zelândia. O Comitê desconsiderou a violação de seu direito à vida uma vez que haviam sido implementadas medidas suficientes em Kiribati. Todavia, na mesma decisão foi esclarecido que os países não podem deportar pessoas que pedem refúgio em decorrência de ameaças relacionadas ao clima, sendo que essas pessoas não precisam provar que enfrentam danos imediatos caso se encontrem em situação de deportação. Mesmo que o pedido do requerente não tenha sido reconhecido, a decisão do Comitê, ao fazer essa ressalva, representa um grande marco, podendo, futuramente, viabilizar o reconhecimento oficial da figura do refugiado ambiental (ONU, 2020).

10 O planeta Terra tem aproximadamente 4,6 bilhões de anos e, durante esse período, sofreu inúmeras modificações para que alcançasse o seu estado atual. Com o intuito de melhor estudar esses eventos e compreender a evolução da Terra, os mesmos são colocados em uma Escala de Tempo Geológico, a qual é composta por unidades geocronológicas denominadas Éron, Era, Período e Época (KOTZÉ, 2016).
} 
A discussão referente a esse tema foi fomentada em 2000, por Paul Crutzen, na ocasião de um colóquio em Cuernavaca no México, em que o químico afirmou que o planeta havia saído do Holoceno ${ }^{11}$ e entrado no Antropoceno. Esse posicionamento foi defendido pelo pesquisador, juntamente com Eugene F. Stoermer, em 2002, em um artigo publicado na revista Nature, em que afirmaram a necessidade de adicionar uma nova época geológica para "salientar que o homem, como espécie, se tornou uma força de magnitude telúrica" (BONNUEIL; FRESSOZ, 2013, p. 12).

A estabilidade do planeta foi uma marca do Holoceno, que consistiu, segundo Veiga, na "moderação e constância ecológicas tão formidáveis que propiciaram decisivos avanços sociais [...]" (DA VEIGA, 2019, p.12), contudo:

[...] eis uma vantagem comparativa que passou a ser desregulada por excessivas influências artificiais de atividades humanas. Então, para distinguir essa nova etapa, em que a durabilidade da vida na Terra passou a depender da conduta de uma única espécie - a humana -, é bem mais apropriado o prefixo Antropo do que Holo (DA VEIGA, 2019, p. 13).

O Antropoceno é o ponto de virada na história da humanidade, na história da vida e na história da própria Terra (LEWS; MASLIN, 2018), pois o ser humano é considerado como um agente geológico capaz de transformar o planeta e colocá-lo em um novo caminho. Com efeito, o Antropoceno sugere que a Terra, agora, deixou sua época geológica atual, o presente estado interglacial chamado de Holoceno. As atividades humanas se tornaram dominantes e profundas que rivalizam com as grandes forças da natureza e empurram a Terra para uma incógnita planetária (STEFFEN; CRUTZEN et al, 2007, p.614).

Cumpre acrescer que a concepção de que a humanidade modificou o planeta não é nova no âmbito da geologia, tendo sido trazida anteriormente por outros termos que também buscavam colocar o ser humano na condição de agente geológico. Ocorre que, no momento de surgimento dessas ideias, ao compararem os impactos da atividade humana com os demais atores geológicos ${ }^{12}$, que já haviam gerando grande impacto na Terra, os primeiros não aparentavam ter a mesma magnitude que os segundos (ZALASIEWICZ; WILLIAMS; STEFFEN; CRUTZEN, 2010).

Atualmente, de modo diferente, quando o ser humano foi colocado na condição de agente geológico pelo Antropoceno, a ideia não foi considerada efêmera. Isso decorre do momento em que o termo foi utilizado, pois percebeu-se que a atividade humana estava de fato alterando a Terra, sendo possível compará-la aos demais eventos geológicos que haviam ocorrido do passado (ZALASIEWICZ; WILLIAMS; STEFFEN; CRUTZEN, 2010).

Logo, as pegadas humanas impactam o meio ambiente e o Sistema Terra de um modo que não havia sido visto anteriormente; consequentemente, essa nova época geológica é objeto de

\footnotetext{
${ }^{11}$ A atual época reconhecida, oficialmente, pela geologia é o Holoceno, que teria começado há aproximadamente 11,65 mil anos atrás, representando o final das grandes glaciações e o início das condições planetárias estáveis que viabilizaram o surgimento e expansão da sociedade moderna (KOTZÉ, 2016).

${ }^{12}$ Como exemplo desses agentes destacam-se: os grandes meteoros, explosões vulcânicas e a modificação dos continentes.
} 
O direito humano a viver em um meio ambiente saudável e equilibrado à luz dos seus vínculos com outros direitos humanos na iminência do pacto global ambiental

debate no Grupo de Trabalho do Antropoceno (Anthropocene Working Group - AWG) ${ }^{13}$, que pretende apresentar uma proposta formal - até 2021 - à Comissão Internacional de Estratigrafia ${ }^{14}$, em que, posteriormente, passará pela análise de vários grupos, com a possibilidade de ser ratificada pelo comitê executivo da União Internacional de Ciências Geológicas (International Union of Geological Sciences - IUGS).

Diferentemente das demais divisões da Escala de Tempo Geológico, as quais foram definidas por meio da comparação de um conjunto de estratos rochosos já consolidado com outro que marcaram o passado da Terra, o Antropoceno é uma época que ainda está sendo vivida, ou seja, "é representado por camadas de sedimentos que se acumularam nos últimos anos" (ZALASIEWICZ; WILLIAMS; STEFFEN; CRUTZEN, 2010, p. 2230), precisando de uma interdisciplinaridade para melhor estudá-lo, incluindo, além de geólogos,"botânicos, zoólogos, cientistas atmosféricos e oceânicos (e outros)" (ZALASIEWICZ; WILLIAMS; STEFFEN; CRUTZEN, 2010. p. 2230).

A questão mais controversa debatida pelos experts da geologia consiste na identificação do momento histórico em que a Terra teria passado do Holoceno para o Antropoceno; alguns acontecimentos já foram elencados, como a Revolução Industrial e a Revolução Tecnológica, mas há uma tendência mais consensual para que esse marco se dê em meados do século passado, "quando as primeiras explosões nucleares coincidiram com o desencadeamento de incomparável surto de progresso material" (DA VEIGA, 2019, p. 13).

Esse marco é apoiado por grande parte do Grupo de Trabalho do Antropoceno, pois consiste em um período em que o rápido crescimento populacional acelerou o ritmo da produção industrial, o uso de químicos agrícolas e outras atividades humanas, sendo que, "ao mesmo tempo, as primeiras explosões de bombas atômicas cobriram o globo com detritos radioativos que foram incorporados em sedimentos e no gelo glacial, [compondo] parte do registro geológico" (SUBRAMANIAN, 2019, s. p.).

Sem embargo, o Antropoceno representa uma nova fase na história da humanidade e da Terra, quando forças naturais e humanas se entrelaçam de modo que o destino de uma determinará o destino da outra. Geologicamente, este é um episódio marcante na história deste planeta. E, ainda que o debate referente à oficialização do Antropoceno esteja concentrado na geologia, trata-se do "conceito filosófico, religioso, antropológico e político mais decisivo e jamais produzido como alternativa às ideias modernas" (LATOUR apud BONNUEIL; FRESSOZ, 2013, p. 33), vez que questiona, de forma profunda, em diversos domínios científicos, as ações humanas e o modo como o ser humano viu e interagiu com o planeta até o presente.

Desse modo, o alerta que é trazido pelo Antropoceno "abre uma nova situação para a humanidade, [bem como] uma nova condição humana" (BONNUEIL; FRESSOZ, 2013, p. 38) em um contexto paradoxal, em que o único responsável pela situação limítrofe vivenciada atualmente, é simultaneamente - aquele que detém o poder e os meios para reverter esse quadro que ameaça todas as formas de vida existentes no planeta.

${ }^{13}$ O Grupo de Trabalho do Antropoceno foi criado para discutir as características e o momento em que essa nova época geológica teria iniciado e, posteriormente, montar uma proposta para que o Antropoceno seja oficialmente reconhecido pela geologia.

${ }^{14}$ International Commission on Stratigraphy (ICS). 
Com efeito, face à gravidade da crise ecológica, que gera incertezas inclusive sobre a própria continuidade da vida na Terra, a resposta no campo jurídico é no sentido de que precisamos de uma intervenção mais forte de longo alcance para que as medidas jurídicas sejam eficazes. Desse modo, - Antropoceno pode legitimar a criação e aplicação de normas mais rígidas, por exemplo, para controlar a emissão de gases de efeito estufa, recuperar e conservar a biodiversidade. Além de servir como embasamento científico para decisões relacionadas à compensação dos danos ambientais.

Por outro lado, com a perspectiva dessa nova época, os seres humanos se encontram obrigados a repensar suas ações em todos os domínios e a buscar uma reintegração junto à natureza e ao sistema terrestre. Com efeito, vale lembrar que no paradigma do constitucionalismo, os direitos fundamentais foram capazes de mudar para melhor o comportamento humano e o destino de muitas políticas de Estado. Assim como o sistema internacional dos direitos humanos, universalmente reconhecidos e vinculantes, se transformou no padrão global mínimo para os Estados, que se violados podem gerar responsabilidades ou desprezo pelos seus pares.

No contexto ambiental, o Antropoceno motiva abordagens mais críticas e mudanças no sistema de governança ambiental global pelo seu caráter de urgência, ao mesmo tempo em que serve como justificativa para se buscar o desenvolvimento do sistema jurídico de proteção ambiental no quadro dos direitos humanos e das leis ambientais internacionais.

\section{O DIREITO HUMANO A VIVER EM UM MEIO AMBIENTE SAUDÁVEL E EQUILIBRADO}

As questões ambientais apresentam uma ligação clara com as problemáticas que envolvem os direitos humanos e, tanto os direitos humanos quanto a proteção ao meio ambiente encontram uma base consolidada no ordenamento jurídico internacional. Uma primeira abordagem que possibilita trabalhar com a intersecção entre os direitos humanos e o meio ambiente, com o intuito de solucionar problemáticas comuns a ambos, se dá pelo reconhecimento do meio ambiente como um direito humano ou, dito de outra forma, pelo direito humano a viver em um meio ambiente saudável e equilibrado.

Contudo, um ponto sensível dessa abordagem consiste na incorporação do meio ambiente como um direito humano pelos documentos internacionais de caráter global. Até o presente momento, a Assembleia Geral da ONU, grande responsável pela inclusão formal dos direitos humanos no corpo do direito internacional, não proclamou o direito humano ao meio ambiente, vinculante aos Estados. Por consequência, é possível dizer que o direito fundamental ao meio ambiente, amplamente reconhecido nas constituições dos Estados pelo mundo, não deriva diretamente, mas sofre inspiração da Declaração Universal de Direitos Humanos.

A Declaração Universal de Direitos Humanos (DUDH) não traz expressamente a proteção ambiental. Isso decorre do momento histórico em que seu texto foi construído pois, em 1948, as questões ambientais ainda não estavam sendo discutidas diretamente no cenário internacional, passando a integrar a agenda a partir da década de 1960 com o nascimento do movimento 
O direito humano a viver em um meio ambiente saudável e equilibrado à luz dos seus vínculos com outros direitos humanos na

ambientalista moderno. Todavia, é possível, por intermédio de uma interpretação da DUDH, inferir um reconhecimento implícito do direito humano ao meio ambiente, como nos artigos $22^{15}, 25.1^{16}, 29.2^{17}$.

Em 1968, no contexto das reivindicações ambientais da década de 1960, a Assembleia Geral da ONU manifestou sua preocupação pelos consequentes efeitos da degradação ambiental na condição humana, no seu bem-estar físico, mental e social, sua dignidade e fruição dos direitos humanos básicos. Desse modo, a Assembleia da ONU endossou a Declaração de Estocolmo, resultado da Conferência das Nações Unidas sobre o Meio Ambiente Humano de 1972.

Essa declaração, mesmo sendo um instrumento de soft law, não vinculante aos Estados, forneceu os primeiros parâmetros para um direito internacional do meio ambiente saudável e equilibrado, destacando o caráter fundamental do direito ao meio ambiente saudável e seu vínculo indissolúvel com a dignidade da pessoa humana. Com efeito, a Conferência de Estocolmo e sua declaração foram capazes de elevar o meio ambiente na imaginação coletiva numa época em que a questão ambiental era apenas um assunto periférico, à margem na formulação de políticas públicas

Além de influenciar as constituições nacionais, a Declaração de Estocolmo inaugurou a visão sobre o meio ambiente como condição prévia ao gozo dos direitos humanos. Logo no preâmbulo declara que: "Ambos os aspectos do meio ambiente, natural e artificial, são essenciais ao bem-estar e ao gozo dos direitos humanos básicos - inclusive o direito à própria vida". Essa proclamação não apenas afirma o caráter fundamental do direito ao meio ambiente saudável, mas também enfatiza a coerência desse direito com todo o corpo dos direitos humanos.

Além disso, o primeiro princípio da Declaração de Estocolmo sobre o meio ambiente humano reconhece expressamente a ligação entre o meio ambiente e uma vida digna. O Princípio 1 proclama que: "O homem tem o direito fundamental à liberdade, igualdade e condições de vida adequadas, em um meio ambiente de qualidade que permita uma vida digna e bem-estar, e ele tem uma responsabilidade solene de proteger e melhorar o meio ambiente para as gerações presentes e futuras". A abordagem baseada no direito à proteção ambiental, que reconhece a importância da integridade ecológica como condição sine qua non para existência humana, trazida pela narrativa da Declaração de Estocolmo, forneceu uma base sólida para o surgimento de todo um corpo de leis internacionais sobre direitos humanos e meio ambiente.

Após 20 anos, aconteceu a Conferência do Rio (Eco-92), e na Declaração do Rio o Princípio $1^{18}$ posicionou os seres humanos no centro das preocupações com o desenvolvimento sustentável,

${ }^{15}$ Art. 22. Toda a pessoa, como membro da sociedade, tem direito à segurança social; e pode legitimamente exigir a satisfação dos direitos econômicos, sociais e culturais indispensáveis, graças ao esforço nacional e à cooperação internacional, de harmonia com a organização e os recursos de cada país.

${ }^{16}$ Art. 25.1. 1.Toda a pessoa tem direito a um nível de vida suficiente para the assegurar e à sua família a saúde e o bem-estar, principalmente quanto à alimentação, ao vestuário, ao alojamento, à assistência médica e ainda quanto aos serviços sociais necessários, e tem direito à segurança no desemprego, na doença, na invalidez, na viuvez, na velhice ou noutros casos de perda de meios de subsistência por circunstâncias independentes da sua vontade.

${ }^{17}$ Art. 29.2. No exercício deste direito e no gozo destas liberdades ninguém está sujeito senão às limitações estabelecidas pela lei com vista exclusivamente a promover o reconhecimento e o respeito dos direitos e liberdades dos outros e a fim de satisfazer as justas exigências da moral, da ordem pública e do bem-estar numa sociedade democrática. 
destacando seu direito a uma vida saudável e produtiva, em harmonia com a natureza. Já nos Princípios $3^{19}$ e $4^{20}$ o foco no direito ao desenvolvimento e no atendimento equitativo das necessidades ambientais das presentes e futuras gerações, coloca a proteção do meio ambiente como parte integrante do processo de desenvolvimento ${ }^{21}$.

A prioridade do direito ao desenvolvimento para satisfação das necessidade humanas, ainda que se integre o meio ambiente nesse processo, se distancia do que o direito humano ao meio ambiente pode proporcionar, do ponto de vista dos limites ecológicos aos objetivos socioeconômicos de bem-estar. Com efeito, na Declaração de Estocolmo o direito humano ao meio ambiente implica sua proteção e melhoramento, considerando que afeta o bem-estar de todos os povos, para além das expectativas do desenvolvimento econômico sustentável enfatizadas na Declaração do Rio-92.

A Declaração de Joanesburgo de 2002 sobre Desenvolvimento Sustentável não incluiu compromissos sobre direitos humanos em nenhuma de suas disposições, mas reafirmou a proteção ambiental e o desenvolvimento socioeconômico como fundamentais ao desenvolvimento sustentável22. Já no Plano de Ação de Joanesburgo houve reconhecimento da relação entre meio ambiente e direitos humanos, dentre eles o direito ao desenvolvimento ${ }^{23}$, mas isso não equivale ao reconhecimento do direito humano ao meio ambiente.

Mais recentemente, em 2012, o documento final da Rio + 20, "O futuro que queremos", reafirmou o respeito por todos os direitos humanos, incluindo o direito ao desenvolvimento e o direito a um padrão de vida adequado ${ }^{24}$ e reconheceu a importância da Declaração Universal dos Direitos Humanos ${ }^{25}$, bem como de outros instrumentos internacionais relacionados aos direitos humanos e ao

18 Os seres humanos estão no centro das preocupações com o desenvolvimento sustentável. Têm direito a uma vida saudável e produtiva, em harmonia com a natureza.

${ }_{19}$ O direito ao desenvolvimento deve ser exercido de modo a permitir que sejam atendidas equitativamente as necessidades ambientais e de desenvolvimento de gerações presentes e futuras.

${ }^{20}$ Para alcançar o desenvolvimento sustentável, a proteção ambiental deve constituir parte integrante do processo de desenvolvimento, e não pode ser considerada isoladamente deste.

21 "O princípio da integração possui papel fundamental e promissor nas relações entre regimes internacionais diversos, pois ajuda a entender como alcançar os resultados sob bases sustentáveis, assim como promove relações sistêmicas entre áreas antes vistas como opostas e hoje entendidas como inter-relacionadas" (LUCENA; REIS; CAMPELLO, 2018, p. 103).

22 Assim, assumimos uma responsabilidade coletiva de avançar e fortalecer os pilares interdependentes e que se reforçam mutuamente do desenvolvimento sustentável - desenvolvimento econômico, desenvolvimento social e proteção ambiental - nos níveis local, nacional, regional e global (UN, 2002).

${ }^{23} \mathrm{Paz}$, segurança, estabilidade e respeito pelos direitos humanos e liberdades fundamentais, incluindo o direito ao desenvolvimento, bem como o respeito à diversidade cultural, são essenciais para alcançar o desenvolvimento sustentável e garantir que o desenvolvimento sustentável beneficie a todos (UN, 2002).

24 8. Reafirmamos também a importância da liberdade, da paz e da segurança, do respeito aos direitos humanos, incluindo o direito ao desenvolvimento e o direito a um padrão de vida adequado, nomeadamente, o direito à alimentação, ao Estado de Direito, à igualdade de gênero e ao empoderamento das mulheres, reafirmando, de forma mais geral, o nosso compromisso com sociedades justas e democráticas para o desenvolvimento (ONU, 2012).

${ }^{25} 9$. Reafirmamos a importância da Declaração Universal dos Direitos Humanos, bem como de outros instrumentos internacionais relativos aos direitos humanos e ao direito internacional (ONU, 2012). 
O direito humano a viver em um meio ambiente saudável e equilibrado à luz dos seus vínculos com outros direitos humanos na

direito internacional ${ }^{26}$. Ao sinalizar um possível afastamento dos direitos antropocêntricos das declarações anteriores, este documento afirma que os direitos da natureza podem desempenhar um papel na promoção do desenvolvimento sustentável27.

Ainda que não haja um reconhecimento expresso do direito humano ao meio ambiente saudável e equilibrado em um documento de caráter global, no âmbito da proteção regional dos Direitos Humanos a situação se difere, pois há previsão desse direito em documentos de caráter regional como na União Europeia ${ }^{28}$ e nos Países Árabes e Asiáticos ${ }^{29}$.

\subsection{O Direito ao Meio Ambiente no Sistema Africano de Proteção dos Direitos Humanos: o Caso Ogoniland}

O primeiro reconhecimento do meio ambiente enquanto direito humano decorre da Carta Africana dos Direitos Humanos e dos Povos ${ }^{30}$ - também conhecida como Carta de Banjul - de 1981, a qual, além de "[traduzir] um progresso significativo no sistema africano, [preenchendo] uma lacuna no que se refere à proteção dos direitos humanos [...]" (SILVEIRA; ROCASOLANO, 2010, p. 169), afirmou o direito dos povos à preservação do equilíbrio ecológico, reconhecendo em seu artigo 24 que "todos os povos têm direito a um meio ambiente geral satisfatório, propício ao seu desenvolvimento" (ORGANIZAÇÃO DA UNIDADE AFRICANA, 1981). Trata-se do reconhecimento de

\footnotetext{
${ }^{26} 87$. Reafirmamos a necessidade de fortalecer a governança ambiental internacional no contexto do quadro institucional para o desenvolvimento sustentável, a fim de promover uma integração equilibrada da situação económica, social e ambiental, dimensões do desenvolvimento sustentável, bem como a coordenação dentro do sistema das Nações Unidas (ONU, 2012).

${ }^{27} 39$. Reconhecemos que o planeta Terra e seus ecossistemas são a nossa casa e que a expressão "Mãe Terra" é comum em vários países e regiões e que alguns países reconhecem os direitos da natureza no contexto da promoção do desenvolvimento sustentável. Estamos convencidos de que, para alcançar um justo equilíbrio entre as necessidades econômicas, ambientais e sociais das gerações presentes e futuras, é necessário promover a harmonia com a natureza (ONU, 2012).

${ }^{28}$ Exemplo disso, em 1998, foi implementada pela União Europeia a Convenção sobre Acesso à Informação, Participação Pública no Processo de Tomada de Decisão e Acesso à Justiça em Matéria Ambiental - conhecida como Convenção de Aarhus - que trouxe, logo no artigo $1^{\circ}$, o direito de todas as gerações - presentes e futuras - a viver em um meio ambiente adequado a sua saúde e bemestar (CEE/ONU, 1998). Todavia, seu mecanismo de compliance se dá apenas para violações dos procedimentos ou direitos de acesso, e não do direito ao meio ambiente propriamente dito.

${ }^{29}$ A Carta Árabe de Direitos Humanos - de 2004 - e a Declaração de Direitos Humanos dos Países do Sudeste Asiático - de 2012 - também contemplam o direito humano a um meio ambiente saudável e equilibrado. A primeira prevê, no artigo 38, o direito a um meio ambiente saudável como parte integrante do direito a um padrão de vida adequado que assegure o bem-estar e uma vida digna; do mesmo modo, a segunda incorpora - no artigo 28.f - o direito a um meio ambiente seguro, limpo e sustentável como parte do direito a um padrão de vida adequado. Porém, assim como ocorre nos outros casos mencionados acima, há dificuldade de tutela desse direito, pois no sistema árabe não há um mecanismo de compliance que possa receber reclamações sobre violações de direitos.

${ }^{30}$ A Carta Africana dos Direitos Humanos e dos Povos é o principal documento do sistema africano, "adotada pela XVIII Conferência dos Chefes de Estado e de Governo dos países africanos, no âmbito da então denominada Organização da Unidade Africana (OUA) - hoje União Africana. A Carta foi proclamada em 26 de junho de 1981, em Nairóbi, no Quênia, e já foi ratificada pela maioria dos Estados-membro da OUA. Entrou em vigor em 21 de outubro de 1986 - isto é, três décadas após a criação do sistema europeu" (SILVEIRA; ROCASOLANO, 2010, p. 168-169).
} 
que um meio ambiente satisfatório é pré-condição para o desenvolvimento econômico, social e cultural, além da realização de outros direitos humanos na África.

Com essa perspectiva, vale recordar o caso Ogoniland - julgado pela Comissão Africana de Direitos Humanos ${ }^{31}$ em 2001 - que teve grande repercussão internacional por tratar de inúmeras violações de direitos humanos ${ }^{32}$, dentre as quais, o direito humano ao meio ambiente previsto no artigo 24 da Carta Africana dos Direitos Humanos e dos Povos. Em 1996, duas organizações nãogovernamentais $^{33}$ apresentaram uma queixa alegando que o governo da Nigéria havia violado inúmeros direitos humanos dos povos Ogoni ao cooperar com a Shell na realização de atividades petroleiras ${ }^{34}$ em seus territórios, além de ter sido omisso em seu dever de fiscalização e deixado - à disposição das companhias petroleiras - as forças de segurança do Estado as quais, segundo denúncias, teriam atacado, queimado e destruído inúmeros vilarejos Ogoni sob o pretexto de desalojar funcionários e apoiadores do Movimento de Sobrevivência do Povo Ogoni (Movement of the Survival of the Ogoni People - MOSOP(5) (COOMANS, 2003).

Por conseguinte, inúmeros problemas emergiram com repercussão na esfera ambiental como a contaminação da água, do solo e do ar - e social, como a destruição de lares, queima de plantações, morte de animais, além do constante medo ao qual esses povos foram expostos (COOMANS, 2003). Nos termos da queixa apresentada, foram alegadas violações do artigo 2036

${ }^{31}$ A Comissão Africana dos Direitos Humanos e dos Povos encontra previsão na Parte II da Carta Africana de Direitos Humanos que trata das medidas de salvaguarda dos direitos assegurados. As competências da Comissão foram estabelecidas no artigo 45ำ e consistem, resumidamente, em: i) promover os direitos humanos e dos povos por meio da reunião de documentações, realização de estudos, formulação de princípios e regras, bem como cooperar com outras instituições africanas ou internacionais; ii) assegurar a proteção dos direitos humanos e dos povos em conformidades com as determinações da Carta; iii) realizar interpretações da Carta. Em contrapartida, a Corte Africana de Direitos Humanos foi instituída pelo Protocolo à Carta Africana dos Direitos Humanos e dos Povos Relativo à Criação da Corte Africana de Direitos Humanos e dos Povos, o qual foi aprovado em 1998 e entrou em vigor, apenas, em 2004. A Corte foi criada para garantir a defesa dos direitos humanos e dos povos na África atuando para complementar e reforçar as funções da Comissão mencionada. Segundo o Protocolo (artigo 5) e o Regimento Interno (artigo 33ㅇ), a Corte pode receber queixas e/ou petições a si apresentadas pela Comissão Africana dos Direitos Humanos.

${ }^{32}$ De modo mais específico, foi alegada a violação dos seguintes artigos da Carta Africana de Direitos Humanos: artigo 2 (não discriminação no gozo de direitos), artigo 4 (direito à vida), artigo 14 (direito à propriedade), artigo 16 (direito à saúde), artigo 18 (direitos de família), artigo 21 (direito dos povos de livremente dispor de suas riquezas e seus recursos naturais) e artigo 24 (direito dos povos a um meio ambiente satisfatório) (COOMANS, 2003).

${ }^{33}$ Social and Economic Rights Action Centre (SERAC) e Centre for Economic and Social Rights (CESR).

${ }^{34}$ A companhia de petróleo estatal da Nigéria, Nigerian National Petroleum Company (NNPC), havia estabelecido uma cooperação com a Shell Petroleum Development Corporation (SPFC) para explorar a atividade petrolífera na região (COOMANS, 2003).

${ }^{35}$ Trata-se de uma organização que representa o povo Ogoni em sua luta pelos direitos humanos e ambientais na Nigéria. Foi fundado na década de 1990 por Ken Saro-Wiwa para denunciar a poluição gerada pelas companhias petroleiras estrangeiras que realizavam suas atividades em terras Ogoni, especialmente a Shell.

${ }^{36}$ Artigo 2. Toda a pessoa tem direito ao gozo dos direitos e liberdades reconhecidos e garantidos na presente Carta, sem nenhuma distinção, nomeadamente de raça, de etnia, de cor, de sexo, de língua, de religião, de opinião política ou de qualquer outra opinião, de origem nacional ou social, de fortuna, de nascimento ou de qualquer outra situação (ORGANIZAÇÃO DA UNIDADE AFRICANA, 1981). 
O direito humano a viver em um meio ambiente saudável e equilibrado à luz dos seus vínculos com outros direitos humanos na

(direito a não discriminação e gozo de direitos), artigo $4^{037}$ (direito à vida), artigo $14^{38}$ (direito à propriedade), artigo $16^{39}$ (direito à saúde), artigo $18^{40}$ (direito à família), artigo $21^{41}$ (direito de livre disposição de riquezas e recursos naturais) e artigo $24^{42}$ (direito ao meio ambiente satisfatório), todos da Carta Africana de Direitos Humanos e dos Povos (COOMANS, 2003).

Destaca-se que, ainda que a admissibilidade da queixa tenha sido reconhecida rapidamente ${ }^{43}$, a Comissão Africana de Direitos Humanos proferiu uma decisão de mérito apenas em outubro de 2001. A demora decorreu de inúmeros fatores, dentre esses a busca por soluções "amigáveis", o atraso no recebimento de respostas por parte do governo nigeriano, mudanças de governo, a duração limitada das sessões da Comissão, além do anseio por uma decisão razoavelmente adequada (COOMANS, 2003, p. 752).

Em seu posicionamento, a Comissão adotou uma abordagem relacionada com os tipos de obrigações ligadas aos direitos humanos violados ${ }^{44}$. Com o intuito de diferenciar e identificar o seu conteúdo, essas foram divididas em dever de respeitar ${ }^{45}$, proteger ${ }^{46}$, promover $^{47}$ e cumprir ${ }^{48}$ determinada obrigação para assegurar o efetivo gozo do direito humano ao qual essa se relaciona.

\footnotetext{
${ }^{37}$ Artigo 4. A pessoa humana é inviolável. Todo ser humano tem direito ao respeito da sua vida e à integridade física e moral da sua pessoa. Ninguém pode ser arbitrariamente privado desse direito (ORGANIZAÇÃO DA UNIDADE AFRICANA, 1981).

${ }^{38}$ Artigo 14. O direito de propriedade é garantido, só podendo ser afetado por necessidade pública ou no interesse geral da coletividade, em conformidade com as disposições de normas legais apropriadas (ORGANIZAÇÃO DA UNIDADE AFRICANA, 1981).

${ }^{39}$ Artigo 16. 1.Toda pessoa tem direito ao gozo do melhor estado de saúde física e mental que for capaz de atingir. [...] (ORGANIZAÇÃO DA UNIDADE AFRICANA, 1981).

${ }^{40}$ Artigo 18. 1.A família é o elemento natural e a base da sociedade. Ela tem que ser protegida pelo Estado, que deve zelar pela sua saúde física e moral [...] (ORGANIZAÇÃO DA UNIDADE AFRICANA, 1981).

${ }^{41}$ Artigo 21. 1.Os povos têm a livre disposição das suas riquezas e dos seus recursos naturais. Este direito exerce-se no interesse exclusivo das populações. Em nenhum caso o povo pode ser privado deste direito [...] (ORGANIZAÇÃO DA UNIDADE AFRICANA, 1981).

${ }^{42}$ Artigo 24. Todos os povos têm direito a um meio ambiente geral satisfatório, propício ao seu desenvolvimento (ORGANIZAÇÃO DA UNIDADE AFRICANA, 1981).

${ }^{43}$ A queixa foi depositada em março de 1996 e em outubro, do mesmo ano já havia sido considerada admissível.

${ }^{44}$ Em inglês: obligations approach.

${ }^{45}$ Conforme indica a decisão da Comissão, a obrigação de respeitar significa que o Estado deve evitar interferir no gozo dos direitos fundamentais, respeitando seus titulares, suas liberdades, autonomia e recursos (ACHPR, 2001).

${ }^{46}$ Nos termos da decisão da Comissão, o dever de proteger relaciona-se com a obrigação de resguardar os titulares do direito frente a terceiros por intermédio de legislações e a provisão de remédios efetivos. Portanto, trata-se de uma obrigação positiva, porque requer que o Estado tome medidas para proteger os titulares de determinado direito (ACHPR, 2001).

${ }^{47}$ Conforme destaca a decisão da Comissão, o dever de promover consiste em uma obrigação a longo prazo e progressiva, em que o Estado deve adotar medidas para que o indivíduo possa exercer o seu direito (ACHPR, 2001).

${ }^{48}$ Nos termos da decisão da Comissão, a obrigação de cumprir requer que o Estado adote medidas positivas para realizar o gozo direito de determinado direito (ACHPR, 2001), por exemplo, para assegurar o direito à educação é necessário que o Estado construa escolas e contrate professores (COOMANS, 2003).
} 
Segundo Coomans (2003, p. 753), o uso deste método "implica que a realização de cada direito [...] da Carta Africana possa envolver deveres [...]", reforçando a concepção de direito-dever ${ }^{49}$.

Após a análise dos fatos, a Comissão Africana de Direitos Humanos julgou procedente as alegações do requerente, reconhecendo a violação do direito humano ao pleno gozo de direitos (artigo 2), do direito à vida (artigo 4), à propriedade (artigo 14), à saúde (artigo 16), à família (artigo 18), à livre disposição de suas riquezas e recursos naturais (artigo 21), ao meio ambiente satisfatório (artigo 24), e, de modo inovador, atentou-se para a violação de direitos que não estão diretamente previstos na Carta Africana, mas que estariam implícitos, como o direito à moradia e à alimentação (COOMANS, 2003).

No que se refere ao conteúdo ambiental, a Comissão reconheceu a importância do meio ambiente limpo e seguro, bem como a sua relação com os demais direitos econômicos e sociais, a qual é reforçada pelo seu impacto na qualidade de vida e segurança individual. Ademais, no que concerne aos deveres ligados a esse direito, afirmou que:

o direito ao meio ambiente saudável [...] impõe obrigações claras ao governo, [requerendo] que o Estado adote medidas [...] para prevenir a poluição e a degradação ambiental, promover a conservação e assegurar um desenvolvimento ecologicamente sustentável e o uso dos recursos naturais [...] (ACHPR, 2001).

Portanto, as obrigações referentes ao direito humano ao meio ambiente saudável, trazido pela Carta Africana, consistem tanto em deveres de respeito quanto de proteção (COOMANS, 2003). Consequentemente, no que tange aos danos ambientais sofridos pelo povo Ogoni, a Comissão determinou que o governo da Nigéria deveria (i) efetuar a limpeza das terras e rios poluídos e danificados pelas atividades das companhias petroleiras; (ii) assegurar a realização de avaliação de impacto ambiental e social em futuros empreendimentos petroleiros; e, (iii) informar adequadamente a população sobre sua exposição aos riscos ambientais e à saúde (COOMANS, 2003).

Ao analisar esse caso é possível verificar a sua relevância para o sistema de proteção dos direitos humanos, pois "[...] demonstra que [...] [as alegações referentes à] violação dos direitos econômicos, sociais e culturais, [bem como] de direitos coletivos, podem ser totalmente judicializadas" (COOMANS, 2003, p. 757).

Do mesmo modo, em matéria do direito humano ao meio ambiente, trata-se de uma decisão ímpar pois, além de admitir a sua violação, a interdependência com os demais direitos humanos e a existência de obrigações ligadas à sua tutela, a Comissão também exigiu que o Estado adotasse diversas técnicas de proteção ambiental, informação e participação pública, acesso à justiça devido aos danos ambientais sofridos e o monitoramento das atividades potencialmente poluidoras.

\footnotetext{
${ }^{49}$ Ainda que no caso em questão a Comissão tenha tratado dos deveres estatais relacionados aos direitos humanos previstos na Carta Africana, é indispensável trazer a ideia de direito-dever, que pode ser vislumbrada, de modo mais amplo, por meio desse posicionamento da Comissão. Ao reconhecer essa "dupla face" dos direitos humanos, admite-se a responsabilidade ética e jurídica tanto por parte do Estado quanto dos indivíduos e demais atores privados - frente ao grupo social e, de modo mais amplo, à comunidade global. Parte-se da compreensão de que, para assegurar os direitos humanos, é necessário também tratar dos deveres que lhes são inerentes.
} 


\subsection{O Direito ao Meio Ambiente no Sistema Interamericano de proteção dos Direitos Humanos e a Opinião Consultiva n. 23/2017}

No cenário americano, o direito ao meio ambiente é contemplado pelo Protocolo Adicional à Convenção Americana sobre Direitos Humanos em Matéria de Direitos Econômicos, Sociais e Culturais ${ }^{50}$ - também conhecido como Protocolo de San Salvador - de 1988, que trouxe, no artigo 11.1, que "toda pessoa tem direito a viver em um meio ambiente sadio [...]" (OEA, 1988). A Convenção Americana sobre Direitos Humanos prevê, expressamente, no artigo 45, 1ํ, e artigo 62, respectivamente, a competência da Comissão e da Corte para receber e analisar queixas concernentes às violações dos direitos humanos estabelecidos na Convenção. Todavia, o direito ao meio ambiente sadio não está incluído na pequena lista de direitos econômicos, sociais e culturais, cuja violação possa ser objeto de reivindicação à Comissão Interamericana de Direitos Humanos.

O que ocorre é que o Protocolo de San Salvador não traz o sistema de petição individual de forma ampla, reconhecendo em seu artigo 19.6 apenas a competência da Comissão e da Corte para atuarem em casos de violação - de forma direta por um Estado Parte - do direito à educação (artigo 13 do Protocolo) e do direito dos trabalhadores de organização sindical e filiação (artigo 8.1 a do Protocolo) ${ }^{51}$; sendo a atuação da Comissão um pouco mais estendida no que tange à elaboração de recomendações e observações nos termos do artigo $19.7^{52}$.

Com efeito, a Corte Interamericana de Direitos Humanos apresenta uma dupla atuação, funcionando tanto como órgão jurisdicional quanto consultivo. Conforme o artigo $64.1^{53}$ da Convenção Americana, os Estados Membros da OEA têm o direito de solicitar Opiniões Consultivas (OC) à Corte

50 “Aprovada na Conferência de São José da Costa Rica em 22 de novembro de 1969, a Convenção [Americana sobre Direitos Humanos] reproduz a maior parte das declarações de direitos constantes no Pacto Internacional de Direitos Civis e Políticos de 1966. [...] A fim de obter a adesão dos Estados Unidos à Convenção, a Conferência de São José da Costa Rica decidiu deixar para um Protocolo à parte a declaração de direitos econômicos, sociais e culturais; Protocolo esse que só veio a ser aprovado na Conferência Interamericana de São Salvador, em 17 de novembro de 1988" (COMPARATO, 2013, p. 379), trazendo direitos como o trabalho, a previdência social, a saúde, a alimentação e o meio ambiente.

${ }^{51}$ Caso os direitos estabelecidos na alínea 'a' do artigo 8, e no artigo 13, forem violados por ação imputável diretamente a um Estado Parte deste Protocolo, essa situação poderá dar lugar, mediante participação da Comissão Interamericana de Direitos Humanos e, quando cabível, da Corte Interamericana de Direitos Humanos, à aplicação do sistema de petições individuais regulado pelos artigos 44 a 51 e 61 a 69 da Convenção Americana sobre Direitos Humanos.

52 Sem prejuízo do disposto no parágrafo anterior, a Comissão Interamericana de Direitos Humanos poderá formular as observações e recomendações que considerar pertinentes sobre a situação dos direitos econômicos, sociais e culturais estabelecidos neste Protocolo em todos ou em alguns dos Estados Partes, as quais poderá incluir no Relatório Anual à Assembleia Geral ou num relatório especial, conforme considerar mais apropriado.

53 Artigo 64.1. Os Estados membros da Organização poderão consultar a Corte sobre a interpretação desta Convenção ou de outros tratados concernentes à proteção dos direitos humanos nos Estados americanos. Também poderão consultá-la, no que lhes compete, os órgãos enumerados no capítulo $X$ da Carta da Organização dos Estados Americanos, reformada pelo Protocolo de Buenos Aires.

Revista do Direito [ISSN 1982-9957]. Santa Cruz do Sul, n. 63, p. 105-130, jan. 2021. https://online.unisc.br/seer/index.php/direito/index 
no que tange à interpretação de direitos elencados na Convenção ou em outros tratados, em matéria de direitos humanos, no âmbito dos Estados americanos.

No exercício dessa função, em 2017, a Corte - a pedido da Colômbia ${ }^{54}$ - emitiu a OC23/2017. Entre os pontos de interesse do movimento de direitos humanos e do setor ambiental, a Corte destaca no parágrafo 47 a inter-relação entre os direitos humanos e proteção ambiental, reconhecendo a existência de uma conexão inegável entre a proteção do meio ambiente e a realização de outros direitos humanos, enquanto a degradação ambiental e os efeitos adversos das mudanças climáticas afetam o gozo efetivo dos direitos humanos. Da mesma forma, indica que as diferentes categorias de direitos constituem um todo indissolúvel que encontra sua base no reconhecimento da dignidade da pessoa humana, a qual exige proteção e promoção permanentes (INTER-AMERICAN COURT OF HUMAN RIGHTS, 2017).

Em relação aos diferentes direitos humanos afetados por problemas ambientais, a Corte afirma, nesta opinião consultiva, que entre os direitos particularmente vulneráveis a danos ambientais estão os direitos à vida, integridade pessoal, vida privada, saúde, água, alimentação, moradia, participação na vida cultural, direito à propriedade e o direito de não ser forçado a deslocar-se. Além disso, a Corte considera que a violação desses direitos pode ocorrer com maior intensidade em certos grupos em situações de vulnerabilidade, motivo pelo qual, com base no direito internacional dos direitos humanos, os Estados estão obrigados a lidar com essas vulnerabilidades, de acordo com os princípios da igualdade e da não discriminação (INTER-AMERICAN COURT OF HUMAN RIGHTS, 2017).

Todavia, ao discutir o tema, a OC-23/2017 não fica restrita ao modo como o dano ambiental pode interferir na esfera dos direitos humanos, ao contrário, amplia o debate para a afirmação do meio ambiente como direito humano. No parágrafo 56 a Corte reitera o reconhecimento expresso, no sistema Interamericano, do direito humano ao meio ambiente sadio. No parágrafo subsequente, acrescenta que a proteção conferida pelo artigo $26^{55}$ - da Convenção Americana sobre Direitos Humanos - aos direitos econômicos, sociais e culturais, também deve ser aplicada ao direito humano ao meio ambiente; portanto, deve-se adotar providências para alcançar a sua progressiva e plena efetividade, ou seja, é necessário buscar o seu desenvolvimento progressivo (INTER-AMERICAN COURT OF HUMAN RIGHTS, 2017).

Do mesmo modo, a progressividade do direito humano ao meio ambiente pode ser interpretada, conforme destaca Prieur (2014), no próprio Protocolo de San Salvador que, no artigo

\footnotetext{
${ }^{54} \mathrm{Em}$ março de 2016 a Colômbia apresentou uma solicitação de Opinião Consultiva à Corte sobre as obrigações dos Estados em relação ao meio ambiente e o marco da proteção e garantia dos direitos à vida e integridade pessoal, a fim de que a Corte determine de que forma deve-se interpretar o Pacto de San José diante do risco - causado por uma nova infraestrutura - ao ambiente marinho na região do Caribe (INTER-AMERICAN COURT OF HUMAN RIGHTS, 2017).

55 Artigo 26. Desenvolvimento progressivo. Os Estados Partes comprometem-se a adotar providências, tanto no âmbito interno como mediante cooperação internacional, especialmente econômica e técnica, a fim de conseguir progressivamente a plena efetividade dos direitos que decorrem das normas econômicas, sociais e sobre educação, ciência e cultura, constantes da Carta da Organização dos Estados Americanos, reformada pelo Protocolo de Buenos Aires, na medida dos recursos disponíveis, por via legislativa ou por outros meios apropriados (OEA, 1969).
} 
O direito humano a viver em um meio ambiente saudável e equilibrado à luz dos seus vínculos com outros direitos humanos na

${ }^{156}$, traz o compromisso dos Estados em alcançar a plena efetividade, de modo progressivo, dos direitos reconhecidos no Protocolo, dentre esses, o direito ao meio ambiente sadio trazido pelo artigo 11.1. Portanto, não há dúvida quanto a necessidade de buscar a efetivação progressiva do direito humano ao meio ambiente saudável e equilibrado.

Consequentemente, o reconhecimento da aplicabilidade da "progressividade, ou progresso contínuo, ligado aos direitos humanos se traduz, juridicamente, por uma proibição de regressão que [passa a repercutir] no direito ambiental" (PRIEUR, 2014, p. 185), fazendo com que a tutela jurídica do direito ao meio ambiente preze pelo seu desenvolvimento progressivo, não admitindo o retrocesso - em termos fáticos e normativos - a um nível de proteção inferior ao já existente ${ }^{57}$ (SARLET; FENSTERSEIFER, 2017).

A ideia de progressividade e vedação de retrocesso, ao tratar do direito humano ao meio ambiente saudável e equilibrado, é de grande importância no âmbito da justiça intergeracional, pois, nos dias atuais, a regressão da qualidade e das condições ambientais representa uma violação do direito das futuras gerações ao meio ambiente. Com efeito, as gerações presentes têm responsabilidade solidária frente às futuras, devendo garantir, no mínimo, um meio ambiente com qualidade não inferior ao que tiveram acesso.

Outro ponto de grande interesse do parágrafo 57 , é que o juiz interamericano afirma que o direito ao ambiente sadio é exigível em casos contenciosos, diretamente perante o sistema interamericano de direitos humanos. Com efeito, o Tribunal reiterou a interdependência e indivisibilidade existente entre direitos civis e políticos e direitos econômicos, sociais e culturais, vez que devem ser compreendidos de maneira global como direitos humanos, sem hierarquia entre si e exigíveis em todos os casos perante as autoridades competentes (INTER-AMERICAN COURT OF HUMAN RIGHTS, 2017).

Ademais, o direito humano ao meio ambiente saudável foi entendido como um direito com conotações individuais e coletivas. Em sua dimensão coletiva, o direito ao meio ambiente constitui interesse universal das gerações presentes e futuras. No entanto, esse direito também possui uma dimensão individual, na medida em que sua violação pode ter repercussões diretas ou indiretas sobre as pessoas devido à sua conexão com os demais direitos, como direito à saúde, integridade pessoal ou vida, entre outros. Afirma a OC-23/2017 que a degradação ambiental pode causar danos

\footnotetext{
${ }^{56}$ Artigo 1. Os Estados Partes neste Protocolo Adicional à Convenção Americana sobre Direitos Humanos comprometem-se a adotar as medidas necessárias, tanto de ordem interna como por meio da cooperação entre os Estados, especialmente econômica e técnica, até o máximo dos recursos disponíveis e levando em conta seu grau de desenvolvimento, a fim de conseguir, progressivamente e de acordo com a legislação interna, a plena efetividade dos direitos reconhecidos neste Protocolo (OEA, 1988).

57 "Essa ideia de garantir um desenvolvimento contínuo e progressivo das modalidades de exercício do direito ao meio ambiente até o nível mais elevado de sua eficácia pode parecer [em um primeiro momento] utópico. A eficácia máxima é a poluição zero. Sabemos que ela não é possível. Mas entre a poluição zero e, [por exemplo], a utilização de melhores tecnologias disponíveis para reduzir a poluição, há uma margem de manobra importante. A não regressão vai se situar entre [o maior padrão de] despoluição possível (que vai evoluir com o decorrer do tempo em decorrência do progresso científico e tecnológico) e um nível mínimo de proteção ambiental que também evolui constantemente. Um recuo hoje não teria sido [necessariamente] um recuo no passado" (PRIEUR, 2014, p. 203).
} 
irreparáveis aos seres humanos, o que torna o meio ambiente saudável um direito fundamental para a existência da humanidade (INTER-AMERICAN COURT OF HUMAN RIGHTS, 2017).

A Corte também apresenta posicionamento vanguardista ao trazer, na OC-23/2017, que o direito ao meio ambiente saudável diferencia-se dos demais pois seu âmbito de preocupação ultrapassa a esfera humana; englobando todos os componentes ambientais (como rios, florestas, mares e outros), os quais passam a ser dotados de interesses legais em si mesmos. Assim, a proteção do meio ambiente e da natureza não decorre apenas da relação existente com o ser humano, mas, também, da sua importância para a manutenção da vida (INTER-AMERICAN COURT OF HUMAN RIGHTS, 2017).

Com efeito, não há dúvidas que a OC-23/2017 mostra avanços quanto à interpretação da relação entre os direitos humanos e meio ambiente no sistema Interamericano, reafirmando, não apenas a interdependência entre o meio ambiente e os demais direitos humanos, mas, também, o meio ambiente na qualidade de direito humano autônomo que diferencia-se dos demais por ser um direito que - além de apresentar uma característica de preocupação intergeracional - também busca tutelar a vida de modo geral, ultrapassando a esfera humana.

O reconhecimento, pelo sistema Interamericano, do direito humano ao meio ambiente sadio como direito autônomo e dotado de característica intergeracional, apenas reitera a necessidade de um pacto pautado no valor de solidariedade que estabeleça obrigações e tutele o direito ao meio ambiente para as presentes e futuras gerações e, de modo mais amplo, para a proteção da vida.

\section{A IMINÊNCIA DO PACTO GLOBAL PARA O MEIO AMBIENTE E SEUS REFLEXOS}

As evoluções referentes à afirmação do direito humano ao meio ambiente - que podem ser verificadas por intermédio dos documentos e decisões jurisdicionais proferidas no âmbito dos sistemas regionais de direitos humanos - colaboraram para o fomento do debate concernente ao estabelecimento do pacto internacional global que regulamenta direitos e obrigações em matéria ambiental.

Todavia, não se trata de uma discussão recente no cenário internacional, pelo contrário, a sua construção pode ser verificada na evolução do sistema internacional de proteção ambiental, com destaque à Conferência de Estocolmo ${ }^{58}$ (1972), que foi a primeira tentativa de adotar uma estrutura global de tutela do meio ambiente (AGUILA; VIÑUALES, 2019). Entretanto, mesmo que a sua configuração não tenha alcançado o pacto global ${ }^{59}$, a Conferência destaca-se na proteção do meio ambiente por introduzir, oficialmente, o debate da matéria no cenário internacional e definir os primeiros parâmetros da governança ambiental global.

${ }^{58}$ Conferência das Nações Unidas sobre o Meio Ambiente Humano, também conhecida como Conferência de Estocolmo.

59 "O contexto internacional não foi, contudo, totalmente favorável a um desenvolvimento tão importante. De fato, a profunda ideologia e política de divisão da Guerra Fria e, não menos importante, a busca de soberania econômica 'permanente' por Estados recém-independentes e outros países em desenvolvimento [influenciaram], em certa medida, o caráter [...] das declarações feitas em Estocolmo" (AGUILA; VIÑUALES, 2019). 
O direito humano a viver em um meio ambiente saudável e equilibrado à luz dos seus vínculos com outros direitos humanos na

Posteriormente, na década de 1980, as discussões ambientais começam a abordar a relevância da proteção ambiental junto ao processo de desenvolvimento. Nesse período, a União Internacional para Conservação da Natureza (International Union for Conservation of Nature - IUCM) elaborou o Projeto de Pacto Internacional sobre Meio Ambiente e Desenvolvimento60 para ser introduzido no processo que levaria à realização da Conferência das Nações Unidas sobre Meio Ambiente e Desenvolvimento61 (AGUILA; VIÑUALES, 2019). Todavia, mesmo que as tentativas de reconhecimento do pacto tenham sido infrutíferas, a IUCN buscou manter a ideia "viva" por meio da revisão e atualização periódica do seu projeto (AGUILA; VIÑUALES, 2019).

Em contrapartida, a adoção de um documento mais universal, que tratasse do meio ambiente, se concretizou com a Declaração de Princípios da Rio 92, que - mesmo sendo um instrumento de soft law62 - "[...] pode ser considerada o passo mais próximo, dado até agora, para formular um conjunto de princípios [...] consensuais e equilibrados para a governança ambiental global" (AGUILA; VIÑUALES, 2019, p. 15).

Ainda na década de 1990, no âmbito dos órgãos de proteção dos direitos humanos da ONU, a Subcomissão de Prevenção da Discriminação e Proteção das Minorias ${ }^{63}$ nomeou Fatma Zohra Ksentini como relatora especial de direitos humanos e meio ambiente que, em 1994, apresentou o seu relatório final (E/CN.4/Sub.2/1994/9) trazendo, em seus anexos, o Projeto de Declaração de Princípios sobre os Direitos Humanos e Meio Ambiente, em que reconhece o direito universal de todas as pessoas ao meio ambiente seguro, saudável e ecologicamente correto (UN, 1994).

Entretanto, "a Comissão de Direitos Humanos considerou o relatório, mas não endossou o projeto de princípios ou nomeou um relator especial [que pudesse the dar continuidade]" (KNOX, 2019). Portanto, mesmo diante da evolução dos debates e declarações que versam sobre o meio ambiente, ainda resta uma lacuna a ser preenchida para aproximar os sistemas de proteção ambiental e de tutela dos direitos humanos que, por muito tempo, tiveram sua afirmação e evolução, no âmbito internacional, construídas de forma paralela.

Em 2015, a Commission Environnement do Clube de Juristas ${ }^{64}$, com base em Paris, publicou o relatório sobre como fortalecer a efetividade do direito ambiental internacional; dentre as 21 recomendações elencadas, destaca-se o elaboração do Pacto Internacional Ambiental (AGUILA; VIÑUALES, 2019). Após a adoção do Acordo de Paris, no mesmo ano, "[...] Laurent Fabius

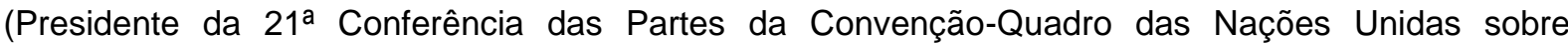

${ }^{60}$ Draft International Covenant on Environment and Development.

${ }^{61}$ Também conhecida como Rio 92.

62 "Apesar de seu valor normativo limitado, as normas de soft law possuem um papel crescente e essencial nas relações internacionais e no desenvolvimento do Direito Internacional, pois, na prática, tais normas muitas vezes são precursoras de negociações de tratados e, ainda, incentivam as práticas de Estado, dando rumo à formação da norma internacional consuetudinária (REIS; CAMPELLO, 2018, p. 93)"

${ }^{63}$ Consiste em um corpo de especialistas independentes que se reporta à Comissão de Direitos Humanos

${ }^{64}$ Criado em 2007, o Clube de Juristas, com base em Paris, é um lugar independente de debates e propostas jurídicas, reunindo profissionais do direito das mais diversas carreiras (magistrados, advogados, professores e outros) para levantar a reflexão em torno dos problemas jurídicos mais salientes. 
Mudança do Clima) decidiu apoiar a ideia e levá-la ao nível internacional" (AGUILA; VIÑUALES, 2019 , p. 20), o que resultou na criação de uma rede internacional de juristas que representam mais de quarenta países do norte e do sul.

Essa rede foi formalizada junto ao Grupo Internacional de Especialistas para o Pacto (Groupe International d'Expert pour le Pacte - GIEP) e, em 2017, na ocasião de um evento internacional realizado na Universidade de Sorbonne, os especialistas apresentaram o projeto do Pacto Global para o Meio Ambiente (GLOBAL PACT FOR THE ENVIRONMENT, [s. d.]).

Posteriormente, em setembro de 2017, o projeto foi levado à ONU, pelo presidente francês Emmanuel Macron, na ocasião da Cúpula Mundial - que reúne inúmeros chefes de Estados - para a celebração do $72^{\circ}$ aniversário da Sessão da Assembleia Geral da ONU. Em maio do ano seguinte, a Assembleia Geral adotou a Resolução A/72/L.5165 - intitulada Rumo a um Pacto Global para o Meio Ambiente (Towards a Global Pact for the Environment) - que viabilizou o início das negociações ao criar o grupo de trabalho ad hoc para estudar as lacunas dos instrumentos de proteção ambiental.

O Pacto Global para o Meio Ambiente tem como objetivo "completar as lacunas existentes no direito internacional ambiental e contribuir para a emergência de um quadro jurídico mundial mais protetivo do equilíbrio natural" (GLOBAL PACT FOR THE ENVIRONMENT, [s.d.]), por intermédio de um tratado multilateral, com força vinculante, visando consagrar os grandes princípios que deverão guiar as ações em matéria ambiental e reconhecer, globalmente, os direitos humanos de terceira dimensão em um pacto que complementaria o "edifício jurídico das normas [...] que compreendem os dois Pactos internacionais [já existentes] [...]” (GLOBAL PACT FOR THE ENVIRONMENT, s.d.).

O conteúdo do projeto é resultado do trabalho de consulta à comunidade internacional, refletindo sua opção por um instrumento conciso, duradouro, adaptável aos diferentes contextos dos países e que equilibre direitos e deveres, princípios novos e aqueles já consolidados, bem como a dimensão normativa e institucional (AGUILA; VIÑUALES, 2019).

Consequentemente, em sua elaboração, optou-se pela criação de normas e princípios gerais. Trata-se "de uma característica comum aos instrumentos que devem [ter] efeitos por longos períodos de tempo, como constituições, tratados de direitos humanos, instrumentos constitutivos de organizações internacionais e assim por diante" (AGUILA; VIÑUALES, 2019, p. 24). Essa ideia também é reforçada pelo fato de que a realidade ambiental, as manifestações da crise ecológica global e as demandas decorrentes desse contexto são mutáveis e exigem respostas cada vez mais rápidas; portanto, faz-se necessário um instrumento atemporal, que possa ser utilizado tanto pelas presentes quanto futuras gerações.

Nesse sentido, o projeto piloto traz, já no primeiro artigo, que cada pessoa tem o direito a viver em um meio ambiente ecologicamente saudável, propício à sua saúde, bem-estar, dignidade, cultura e desenvolvimento pessoal; afirmando, desse modo o direito humano ao meio ambiente. Importante destacar que, de forma estratégica, no artigo subsequente há o reconhecimento do dever

\footnotetext{
${ }^{65}$ A referida resolução teve um grande quórum a favor do Pacto, a mesma contou com 143 votos a favor de sua aprovação, apenas 5 votos contra (Estados Unidos, Rússia, Síria, Turquia e Filipinas) e 7 abstenções (Arábia Saudita, Belarus, Irã, Malásia, Nicarágua, Nigéria e Tajiquistão) (GLOBAL PACT FOR THE ENVIRONMENT, [s.d.]).
} 
O direito humano a viver em um meio ambiente saudável e equilibrado à luz dos seus vínculos com outros direitos humanos na

de cuidar do meio ambiente, que é inerente aos Estados, às instituições internacionais e a toda pessoa, física ou jurídica, pública ou privada (GIEP, 2017).

Essa proposta é um marco de grande relevância pois é adotada a abordagem do meio ambiente na qualidade de direito-dever, em que se reconhece o direito humano ao meio ambiente, mas, também, afirma-se que a proteção ambiental é um dever solidário de todos frente às presentes e futuras gerações; colocando em evidência a solidariedade enquanto valor basilar dos direitos humanos de terceira dimensão.

Ainda, o projeto do Pacto Global traz, em seu artigo 11, o direito de acesso efetivo à justiça em matéria ambiental - nas esferas administrativas e judiciárias - para a busca da reparação de danos e contestação de ações ou omissões das autoridades públicas e também de pessoas privadas (GIEP, 2017). A previsão desse dispositivo é de suma relevância para a proteção do direito humano ao meio ambiente, pois reconhece que se trata de um direito exigível em casos contenciosos, tanto em se tratando de ações quanto de omissões e independente da natureza jurídica do polo passivo da ação.

Essa previsão consiste em um avanço necessário para a tutela do direito humano ao meio ambiente, pois, mesmo com as evoluções já verificadas nos sistemas regionais e nas decisões jurisprudenciais que protegem o meio ambiente de forma reflexa - a partir da sua relação com os demais direitos humanos judicializáveis - ainda existem lacunas no que tange à possibilidade de buscar diretamente a referida tutela.

Em contrapartida, a aprovação do Pacto e a definição de suas características estão ligadas ao cenário socioeconômico e político em que as negociações serão realizadas. No ano de 2019 , durante os encontros do grupo de trabalho, os Estados tiveram a oportunidade de se reunirem em três ocasiões na cidade de Nairóbi e, no terceiro encontro, as recomendações se afastaram da proposta original do Pacto, optando por adotar uma Declaração política - e não mais um instrumento vinculante - no ano de 2022 (não mais para os anos de 2020-2021).

Essas últimas recomendações não vão ao encontro da realidade que se verifica nos âmbitos regionais e nacionais de proteção do direito humano ao meio ambiente, em que, no total, pelo menos 155 Estados já reconheceram o direito ao meio ambiente saudável - e os deveres ambientais - por intermédio de tratados, constituições e legislações (BOYD, 2019). Esse panorama deve ser considerado e apresenta uma "base convincente para as Nações Unidas avançarem rapidamente para [a afirmação] global do direito ao ambiente saudável [...]" (BOYD, 2019, p. 33).

Insta destacar que "a Assembleia Geral da ONU têm sido historicamente cuidadosa em não proclamar novos direitos humanos sem revisão [adequada]; e, em 1986, [com a Resolução $\mathrm{A} / \mathrm{RES} / 41 / 120]$, adotou diretrizes para o reconhecimento de novos instrumentos de direitos humanos [...]" (KNOX, 2019), exigindo que esses:

(i) sejam consistentes com o corpo existente do direito internacional dos direitos humanos; (ii) tenham caráter fundamental e sejam derivados da dignidade e dos valores inerentes à pessoa humana; (iii) sejam suficientemente precisos para gerar direitos e obrigações identificáveis e práticos; (iv) forneçam, quando apropriado, maquinário de implementação 
realista e eficaz, incluindo sistemas de relatórios e (v) atraiam amplo apoio internacional (UN, 1986, p. 179).

É possível alegar que o direito humano ao meio ambiente saudável e equilibrado satisfaz esses preceitos, pois, desde a Declaração de Estocolmo (1972) reconhece-se o seu caráter fundamental e sua relação com a dignidade da pessoa humana, afirmando, inclusive, que essa têm uma dimensão ecológica. Do mesmo modo, "a aplicação dos direitos humanos em questões ambientais demonstra sua consistência com os demais direitos humanos de modo suficiente para identificar obrigações práticas" (KNOX, 2019, p. 45), as quais são reforçadas pela noção de deveres ambientais. No que concerne ao apoio internacional, conforme já mencionado, é possível verificá-lo tanto no contexto regional quanto nacional de proteção aos direitos humanos. Por fim, em matéria da implementação eficaz, segundo Orellana (apud KNOX, 2019), essa questão é um desafio concernente a praticamente todos os direitos humanos, no entanto:

[...] a implementação do direito humano ao meio ambiente saudável no nível nacional já está acontecendo em inúmeros países; [no mais], mecanismos internacionais - como revisões periódicas, órgãos de tratados de direitos humanos, tribunais regionais e detentores de mandatos especiais junto ao Conselho de Direitos Humanos - também já estão examinando questões ambientais (KNOX, 2019, pp. 45-46).

Deste modo, o cenário apresenta-se a favorável à afirmação global do direito humano ao meio ambiente. Ademais, esse reconhecimento pode ocasionar inúmeras repercussões positivas no ordenamento jurídico internacional, conforme Knox (2019): i) aumentaria a conscientização e reforçaria a interdependência entre os direitos humanos e a proteção ambiental; ii) destacaria que a proteção do meio ambiente deve receber o mesmo nível de relevância que os demais interesses relacionadas à dignidade humana, igualdade e liberdade; iii) integraria as normas de direitos humanos que têm relação com o meio ambiente, auxiliando em seu desenvolvimento de modo coerente, consistente e integrado; iv) ajudaria a dirigir maior atenção àqueles que se encontram em situação de risco ambiental; e v) os componentes procedimentais (acesso à informação, participação e remédios eficazes) conferiram poderes aos indivíduos e às comunidades para garantirem melhores condições ambientais.

Ao reconhecer o direito humano ao meio ambiente equilibrado e saudável, o Pacto Global para o Meio Ambiente "tem o potencial de contribuir para uma abordagem baseada em direitos [e deveres] para a proteção ambiental" (KNOX, 2019, p. 46) e fortalecer a relação entre os direitos humanos e o meio ambiente, permitindo buscar a proteção do meio ambiente diretamente por intermédio dos sistemas jurisdicionais de tutela dos direitos humanos.

Logo, conforme demonstrado, não restam dúvidas quanto aos benefícios decorrentes da afirmação do direito humano ao meio ambiente equilibrado e saudável por meio de um instrumento de caráter universal. Por fim, ainda que esse reconhecimento necessário esteja em construção, o próprio debate da matéria pelo grupo de juristas e pelo grupo ad hoc da ONU pode ser considerado como avanço resultante de décadas de esforços internacionais em prol da proteção do meio ambiente. 


\section{CONSIDERAÇÕES FINAIS}

A crise ambiental global é o grande desafio a ser enfrentado pela humanidade no século XXI. As buscas por respostas põem em xeque inúmeros pilares que fundamentaram a construção da sociedade contemporânea. É indubitável que o ser humano encontra-se no centro das origens da crise ambiental que, atualmente, ameaça todas as formas de vida existentes na Terra, inclusive aquelas que não contribuíram para o desencadeamento dessa situação limítrofe.

A referida questão é evidenciada pelo marco temporal do Antropoceno que colocou o homem, na história do planeta, como agente geológico, cujas ações causaram grandes impactos no meio ambiente ao ponto de influenciar a formação geológica da Terra e estabelecer a ruptura com o Holoceno. Ainda que as origens desse conceito estejam centradas na geologia, suas implicações irradiam para inúmeras áreas do conhecimento, inclusive, para o Direito, que deve moldar-se com o propósito de buscar soluções diante dos desafios que acompanham essa nova época.

$\mathrm{Na}$ conjuntura ambiental, o Antropoceno representa a urgência por respostas eficazes, fomentando abordagens mais críticas do sistema de governança ambiental e, simultaneamente, justificando o aperfeiçoamento da proteção do meio ambiente no contexto dos direitos humanos e das leis ambientais internacionais.

Ao buscar a afirmação do direito humano ao meio ambiente, foi verificada sua previsão nos sistemas regionais de proteção aos direitos humanos. Todavia, apenas os sistemas Africano e Interamericano apresentam mecanismos que podem ser utilizados para sua tutela.

No sistema Africano, o direito humano ao meio ambiente foi consagrado no artigo 24 da Carta Africana de Direitos Humanos e dos Povos (1981) podendo, inclusive, ser objeto de tutela jurisdicional perante a Comissão e a Corte Africana de Direitos Humanos. Como exemplificação, destacou-se o caso Ogoniland (2001) que foi discutido perante à Comissão, cuja decisão reconheceu a interdependência do direito ao meio ambiente com os demais direitos humanos e admitiu a abordagem de direito-dever ao anunciar que a realização dos direitos previstos na Carta Africana relaciona-se com a observância de obrigações.

Já no sistema Interamericano, o direito humano ao meio ambiente sadio foi previsto no artigo 11.1 do Protocolo de San Salvador. Entretanto, esse direito não foi incluído na lista reduzida dos direitos econômicos, sociais e culturais que podem ser objeto de tutela perante à Comissão Interamericana de Direitos Humanos. Em contrapartida, em 2017, a Corte Interamericana de Direitos Humanos $(\mathrm{CIDH})$, no exercício de sua competência consultiva, emitiu a Opinião Consultiva n. 23/2017, a qual trouxe inúmeros avanços, com destaque à previsão de exigibilidade - em casos contenciosos - do direito humano ao meio ambiente.

A OC n. 23/2017 representa a construção de um novo paradigma no sistema Interamericano, vez que - além de reconhecer que a efetivação de inúmeros direitos humanos encontra-se diretamente relacionada com a proteção ambiental - a Corte declarou que o direito humano ao meio ambiente é autônomo e dotado de caráter individual e coletivo. Com efeito, não há dúvida quanto a existência do direito humano ao meio ambiente no contexto Interamericano; entretanto, permanece o 
desafio concernente à busca efetiva de sua tutela, a qual começou a avançar com o novo entendimento proferido pela $\mathrm{CIDH}$.

Ainda, insta destacar que, além da previsão nos sistemas regionais, o direito humano ao meio ambiente foi incorporado, na qualidade de direito fundamental, por mais de noventa textos constitucionais ao redor do mundo. Consequentemente, demonstrou-se que há um consenso internacional referente a existência do direito humano ao meio ambiente (sadio, saudável, equilibrado ou durável). Todavia, contrariamente à evolução verificada nos níveis regionais e nacionais, nenhum acordo consagrando expressamente o direito humano ao meio ambiente emergiu no nível global.

O sistema universal de proteção aos direitos humanos e o de governança ambiental tiveram sua construção - no âmbito internacional - de forma paralela. Atualmente, na busca de respostas às demandas que decorrem do Antropoceno e da crise ambiental, é necessário trabalhar com a intersecção desses dois sistemas que se mostram suficientemente consolidados e desenvolvidos para tanto.

Com efeito, fomentou-se o debate do tema e, nos últimos anos, emergiu o projeto de Pacto Global para o Meio Ambiente, o qual afirma o direito humano ao meio ambiente equilibrado e saudável por intermédio de um instrumento com normas e princípios gerais que podem ser adaptados às novas demandas de tutela ambiental que venham a se manifestar futuramente.

Ademais, o projeto também incorporou - no artigo 11 - o acesso à justiça em matéria ambiental, tornando possível a tutela jurisdicional do direito humano ao meio ambiente. Essa previsão é de suma importância, pois torna admissível a exigência de proteção do meio ambiente no sistema universal de direitos humanos, em face de ações e omissões.

É evidente que, até o presente momento, o Pacto Global para o Meio Ambiente está em construção; mas, a sua iminência representa um grande avanço para a proteção do meio ambiente em prol das presentes e futuras gerações. Portanto, a sua adoção mostra-se necessária tanto para a tutela ambiental quanto para fechar o sistema global de proteção dos direitos humanos, reunindo juntamente aos dois Pactos internacionais existentes - o terceiro que resguarda os direitos humanos de terceira dimensão.

\section{REFERÊNCIAS}

ACHPR. Communication $\quad$ n. 155/96. 2001. Disponível em: https://www.achpr.org/public/Document/file/English/achpr30 15596 eng.pdf. Acesso em: 13 abr. 2020.

AGUILA, Yann; VIÑUALES, Jorge E. A Global Pact for the Environment - Legal Foundations. [S. I.]: University of Cambridge; CEENRG, mar. 2019.

ANTON, Donald K.; SHELTON, Dinah L. Environmental Protection and Human Rights. New York: Cambridge University Press, 2011.

ARAB COMMISSION ON HUMAN RIGHTS. Carta Árabe de Direitos Humanos. 2004. ASEAN. Declaração de Direitos Humanos dos Países do Sudeste Asiático. 2012.

BONNEUIL, Christophe; FRESSOZ, Jean-Baptiste. L'Événement Anthropocène: la Terre, l'histoire et nous. [S.I.] : Éditions du Seuil, 2013. 
O direito humano a viver em um meio ambiente saudável e equilibrado à luz dos seus vínculos com outros direitos humanos na

BOYD, David R. The Right to a Healthy and Sustainable Environment. In: AGUILA, Yann; VIÑUALES, Jorge E. A Global Pact for the Environment - Legal Foundations. [S. I.]: University of Cambridge; CEENRG, mar. 2019.

CAMPELLO, Lívia Gaigher Bósio; LIMA; Rafaela de Deus. O princípio da cooperação internacional em face às fronteiras planetárias. Revista Argumentum. Marília, v. 19, n. 2, 2018.

CARSON, Rachel. Primavera Silenciosa. São Paulo: Gaia, 2010.

CEE/ONU. Convenção sobre Acesso à Informação, Participação do Público no Processo de Tomada de Decisão e Acesso à Justiça em Matéria Ambiental. 1998.

CHACÓN, Mario Peña. Derechos Humanos Ambientales. [S.I], [s.v.], [s. n.], [s.d.]. Disponível em < https://www.academia.edu/34561035/Derechos Humanos Ambientales>. Acesso em dez. 2019.

COMPARATO, Fábio Konder. A afirmação histórica dos direitos humanos. 8 ed. São Paulo: Saraiva, 2013.

CONSELHO DA EUROPA. Convenção Europeia de Direitos do Homem. 1950.

COOMANS, Fons. The Ogoni Case Before the African Commission on Human and Peoples' Rights. International and Comparative Law Quarterly, [s.I], v. 52, n. 3, 2003, pp. 749-760.

DA VEIGA, José Eli. O Antropoceno e a ciência do Sistema Terra. São Paulo: Editora 34, 2019.

EUROPEAN COURT OF HUMAN RIGHTS. Case López Ostra v. Spain. Strasbourg, 1994. Disponível em <https://hudoc.echr.coe.int/eng\#\{\%22itemid\%22:[\%22001-57905\%22]\} >. Acesso em $08 \mathrm{dez}$. 2019.

FAO. The State of the World's Forests. Rome: Licence, 2018.

GIEP. Anteprojeto Pacto mundial pelo meio ambiente. 2017.

GLOBAL PACT FOR THE ENVIRONMENT. The Pact. [s.d.]. Disponível em < https://globalpactenvironment.org/en/the-pact/>. Acesso em 06 dez. 2019.

GRIFFIN, Nicholas J. Constitutional Rights to a Healthy Environment. In: UNITED NATIONS INSTITUTE FOR TRAINING AND RESEARCH. Constitutional Rights to a Healthy Environment: lesson 3.1. [S.I], [s.d.].

INTER-AMERICAN COURT OF HUMAN RIGHTS. Advisory Opinio OC-23/17. 2017.

KISS, Alexandre; BEURIER, Jean-Pierre. Droit International de l'environnement. 3 ed. Paris : Editions A. Pedone, 2004.

KNOX, John $\mathrm{H}$. The Global Pact for the Environment: at the crossroads of human rights and the environment. Review of European, Comparative \& International Environmental Law, n. 1, v. 28, 2019, pp. 40-47. DOI: 10.1111/reel.12287.

KOTZÉ, Louis J. Global Environmental Constitutionalism in the Anthopocene. [S.I.]: Hart Publishing, 2016.

LEWS, Simon; MASLIN, Mark A. The Human Planet: how we created the Anthropocene. [S.I.]: Yale University Press, 2018.

LUCENA, Micaella Carolina de; REIS, João Henrique Souza dos; CAMPELLO, Lívia Gaigher Bósio. O princípio 4 da declaração do Rio-92: integração e desenvolvimento sustentável. In: CAMPELLO, Lívia Gaigher Bósio; SOUZA, Maria Cláudia Antunes de; SANTIAGO, Mariana Ribeiro (Coord). Meio Ambiente e Desenvolvimento: os 25 anos da Declaração do Rio de 1992. São Paulo: IDHG, 2018. 
OEA. Protocolo de San Salvador. 1988.

ONU. Decisão de comitê da ONU pode impulsionar pedidos de refúgio por mudanças climáticas. 21 jan. 2020. Disponível em <https://nacoesunidas.org/decisao-de-comite-da-onu-pode-impulsionarpedidos-de-refugio-por-mudancas-climaticas/>. Acesso em 02 mar. 2020.

Relatório Mundial das Nações Unidas sobre Desenvolvimento dos Recursos Hídricos. 2019.

Resolução A/72/L.51. 2018.

ORGANIZAÇÃO DA UNIDADE AFRICANA. Carta Africana dos Direitos Humanos e dos Povos. 1981.

OST, François. A natureza à margem da lei: a ecologia à prova do direito. Lisboa: Instituto Piaget, 1997.

PORTUGAL. [Constituição (1976)]. Constituição da República Portuguesa de 1976. Portugal. Disponível em $<$ https://www.parlamento.pt/Legislacao/Paginas/ConstituicaoRepublicaPortuguesa.aspx>. Acesso em 06 dez. 2019.

PRIEUR, Michel. Droit de l'environnement, droit durable. Belgique: Bruylant, 2014.

REIS, João Henrique dos; CAMPELLO, Lívia Gaigher Bósio. Razões para a utilização de normas de soft law no direito internacional do meio ambiente. Revista Brasileira de Direito Internacional, Salvador, v. 4, n. 1, 2018, pp. 83-103.

RISHMAWI, Mervat. The Arab Charter on Human Rights and the League of Arab States: an update. Human Rights Law Review, v. 10, n. 1, 2010, pp. 169-178.

SARLET, Ingo Wolfgang; FENSTERSEIFER, Tiago. Direito ambiental: introdução, fundamentos e teoria geral. São Paulo: Saraiva, 2014.

Princípios do direito ambiental. 2. ed. São Paulo: Saraiva, 2017.

SILVEIRA, Vladmir Oliveira da; ROCASOLANO, Maria Mendez. Direitos humanos: conceitos, significados e funções. São Paulo: Saraiva, 2010.

STEFFEN, Will; CRUTZEN, Paul J.; MCNEILL, John. The Anthropocene: are Humans now overwhelming the Great Forces of Nature?. Ambio, v. 36, n. 8, [S.I], 2007.

SUBRAMANIAN, Meera. Anthropocene now: influential panel votes to recognize Earth's new epoch. Nature. [S.I], 2019. Disponível em <https://www.nature.com/articles/d41586-019-01641-5>. Acesso em 09 dez. 2019.

UN. E/CN.4/Sub.2/1994/9. 1994. Disponível em: https://undocs.org/E/CN.4/SUB.2/1994/9. Acesso em 20 abr. 2020.

Framework Principles on Human Rights and the Environment. 2018.

Johannesburg Declaration on Sustainable Development. Johannesburg, 2002. Disponível em <http://www.un-documents.net/jburgdec.htm>. Acesso em 03 mar. 2020.

Plan of Implementation of the World Summit on Sustainable Development. Johannesburg, 2002. Disponível em <https://www.un.org/esa/sustdev/documents/WSSD_POI_PD/English/POIToc.htm>. Acesso em 03 mar. 2020.

Resolution A/RES/41/120. 1986. Disponível em: https://undocs.org/A/RES/41/120. Acesso em 24 abr. 2020.

Revista do Direito [ISSN 1982-9957]. Santa Cruz do Sul, n. 63, p. 105-130, jan. 2021. https://online.unisc.br/seer/index.php/direito/index 
O direito humano a viver em um meio ambiente saudável e equilibrado à luz dos seus vínculos com outros direitos humanos na

Sixth Global Environment Outlook. 2019.

UNHRC. Report A/HRC/10/61. 2009.

Rapport de l'Expert indépendant chargé d'examiner la question des obligations relatives aux droits de l'homme se rapportant aux moyens de bénéficier d'un environnement sûr, propre, sain et durable (A/HRC/22/43). 2013.

WHO. Air pollution and child health: prescribing clean air. [S.I], 2018.

ZALASIEWIC, Jan; WILLIAMS, Mark; STEFFEN, Will; CRUTZEN, Paul. The new world of the Anthropocene. Environmental Science \& Technology. v. 44, n. 7, [S. I.], 2010. 